Зайцева І., Заслужена А. Специфіка мистанційного навчання за умов пандемії ...

УДК 371.315:811.111

DOI https://doi.org/10.24919/2308-4863/34-2-41

Ірина ЗАЙЦЕВА,

orcid.org/0000-0001-6556-0779

кандидат педагогічних наук,

дочент кафедри іноземної філологї та перекладу

Київського національного торговельно-економічного університету

(Київ, Україна) Irenenazaruk8@gmail.com

Алла ЗАСЛУЖЕНА,

orcid.org/0000-0001-5628-790X

кандидат педагогічних наук,

доцент кафедри іноземної філології

Наиіонального авіаційного університету

(Київ, Україна) allabox1303@gmail.com

\title{
СПЕЦИФІКА ДИСТАНЦЙНОГО НАВЧАННЯ ЗА УМОВ ПАНДЕМІЇ КОРОНАВІРУСУ
}

У статті визначено сучасний стан розвитку дистанщійного навчання у вищих навчальних закладах Украӥни під час пандемії коронавірусу. Визначено особливості реалізаиї освітнього процесу за умов пандемії. Розкрито поняття «дистанційне навчання» щзодо сучасних реалій. Описано принципи дистанційного навчання: гуманістичності, пріоритетності педагогічного підходу, відповідності технологій навчання, гнучкості, модульний принции навчання, неперервності навчання, відкритості навчання. 3 'ясовано, щзо основними перевагами дистаниійного навчання під час пандемії є: формування нового освітнього простору, рівні можливості одержсання освіти, навчання за найбільш зручних умов, розвиток уміння самостійно приймати відповідальні рішення, посилення мотивації.

Розкриті ризики, які можуть спіткати викладачів і студентів у процесі дистаниійного навчання за умов пандемії, такі як: суперечності між великою кількістю ресурсів для таких форматів навчання та відсутністю якісних ресурсів; між потребою в єдиних універсальних платформах і їх відсутністю або недостатньою потужністю для масового використання; між необхідністю адаптувати програму, організацію навчання до дистанційного та зміманого формату і відсутністю у багатьох викладачів умінь для цьього. Акцентовано увагу на підготовці освітян українських вишів до реалізації дистанційного навчання, його ефективної організації.

Проаналізовано психологічні аспекти дистанційного навчання за умов пандемії як для освітян, так $і$ для здобувачів освіти. Визначено основні вимоги до сучасних студентів під час дистанційного навчання, а саме: наявність навичок самостійної роботи, умінь швидко адаптуватися до умов, шчо змінюються непередбачувано та стрімко, формування та розвиток необхіднх умінь і навичок для роботи на навчальних дистанційних платформах.

Аналіз сучасних вимог, труднощів дистанційного навчання, наш власний педагогічний досвід і досвід наших колег із закордонних університетів дозволяють нам проаналізувати пріоритетні стратегї забезпечення та впровадження якісного навчального процесу у кризовій ситуації та розглянути пріоритетні завдання для університетів.

Ключові слова: дистанційне навчання, особливості, вищий навчальний заклад, пандемія, труднощі, система освіти. 
Iryna ZAYTSEVA, orcid.org/0000-0001-6556-0779 Candidate of Pedagogical Sciences, Associate Professor at the Department of Foreign Philology and Translation Kyiv National University of Trade and Economics (Kyiv, Ukraine) Irenenazaruk8@gmail.com

\author{
Alla ZASLUZHENA, \\ orcid.org/0000-0001-5628-790X \\ Candidate of Pedagogical Sciences, \\ Associate Professor at the Department of Foreign Philology \\ National Aviation University \\ (Kyiv,Ukraine) allabox1303@gmail.com
}

\title{
SPECIFICS OF DISTANCE LEARNING DEVELOPMENT DURING CORONAVIRUS PANDEMIC
}

The article identifies the current state of distance learning development in higher educational establishments of Ukraine during coronovirus pandemic. The article deals with the peculiarities of the educational process organization under the conditions of pandemic. The concept of "distance learning" due to today reality has been revealed. The principles of distance learning are described such as humanistic, the priority of pedagogical approach, conformity of learning technologies, flexibility, a modular principle of learning, continuity of learning, openness of learning. It has been found that the main advantages of distance learning during a pandemic are: the formation of new educational space, equal opportunities for education, training in the most convenient conditions, development of ability to make responsible decisions independently; increasing motivation.

The risks that may befall educators and students during distance learning under the conditions of Covid-19 pandemic have been disclosed such as the contradictions between the large number of educational resources for distance learning and the lack of quality resources; between the need for single educational online universal platforms and the lack or insufficient capacity for their use; between the need to adapt the syllabus, the organization of training to a distance and blended learning and the lack of skills for many educators, etc. Attention is focused on the training of educators in Ukrainian higher educational institutions due to distance learning realization and its effective management.

The psychological aspects of distance learning in a pandemic for both educators and students are analyzed. The basic requirements to modern students during distance learning have been determined, in particular: the formation of skills to work independently, the ability to quickly adapt to conditions that are changing unpredictably and rapidly, formation and development of necessary skills and abilities for working on educational online platforms.

The analysis of today requirements, the difficulties of distance learning, our own pedagogical experience and the experience of our colleagues at foreign Universities allow us to analyze the priority strategies to ensure and implement a quality educational process in a crisis situation and to consider the priority tasks for universities.

Key words: distance learning, peculiarities, higher educational establishment, pandemic, difficulties, system of education.

Постановка проблеми. Пандемія коронавірусу є великим глобальним викликом для всієї світової освітянської спільноти, у т. ч. для викладачів і студентів вищих навчальних закладів України. Для протидії пандемії у березні 2020 р. розпочалося впровадження системи дистанційного навчання в освітню практику нашої країни. Розпочався пошук і відпрацювання ефективних підходів для організації навчального процесу за умов пандемії.

Стає очевидним той факт, що вища освіта вже ніколи не буде такою, як раніше, і це є світовою тенденцією: попит на вищу освіту зменшується за умов пандемії, а боротьба за споживачів освітніх послуг зростатиме в найближчі роки. Отже, ми повинні бути конкурентоспроможними й адаптуватися до нових реалій, оскільки змінюється не лише формат навчання, змінюються також ринок $\mathrm{i}$ роботодавці, формуються нові тренди, яким учасники освітнього процесу мають відповідати.

Розвиток комп'ютерних технологій значним чином вплинув на освітній процес у плані розширення можливостей для онлайн-освіти. Про важливість розвитку цього напряму йдеться у низці державних документів: проєкті Концептуальних засад державної політики щодо розвитку англійської мови у сфері вищої освіти, Концепції розвитку педагогічної освіти (Концептуальні засади державної політики, 2020; Концепція розвитку, 2020). Впровадження форм онлайн-навчання потребує більшої інтенсивності, але, маючи достатньо можливостей для денного очного навчання, заклади освіти лише почали здійснення такого навчання на рівні змішаного та дистанційного. 
Зайцева І., Заслужена А. Специфіка дистанційного навчання за умов пандемії ...

Означені аспекти актуалізують потребу наукового осмислення питання успішного впровадження дистанційного навчання, а саме реалізації якісного освітнього процесу в українських вишах за умов пандемії.

Аналіз досліджень. Проблема дистанційного навчання у вищій школі під час пандемії коронавірусу становить значний інтерес для науковців. Дистанційне навчання широко використовується у світовій практиці та є об'єктом зарубіжних досліджень (Дж. Андерсен, Т. Бейтс, Дж. Боат, Р. Гаррісон, Т. Еванс, Д. Кіген, А. Кей, Г. Кірслей, М. Мур, Х. Ператон, О. Петерс, Г. Рамбл, Д. Сьюарт, Б. Гольмберг, Д. Шейл, Е. Шілз та ін.). Українські вчені почали працювати над дистанційним навчанням із 1996 р. (В. Биков, Н. Бастун, I. Зимня, С. Коротаєва, О. Мещерякова, В. Панов, С. Сисоєва, М. Шевандрін).

Специфіці дистанційного навчання під час пандемії коронавірусу присвячені декілька публікацій: дослідження I. Прокопенко, С. Бережної, спрямоване на аналіз труднощів під час навчального процесу, які постали перед викладачами вишів і студентами під час пандемії (Prokopenko, Berezhna, 2020: 130-135). Заслуговує на увагу праця Ю. Клапківа, Т. Длухопольської, у якій проаналізовано зміни в освітньому процесі у вищих навчальних закладах України та Польщі (Клапків, Длухопольська, 2020: 86-91). Зарубіжні вчені Г. Тем, Д. Ел-Азар висвітлили особливості впровадження інноваційних технологій і формування державно-приватного партнерства в освіті під час пандемії (Tam \& El-Azar, 2020).

Висновки та положення, зроблені цими та іншими вченими, мають велику наукову цінність для нашого дослідження. У контексті зазначених вище праць можна відзначити, що у сучасній науковій літературі висвітлені окремі аспекти організації дистанційного навчання, але комплексно проблема вивчення специфіки дистанційного навчання у вишах України та його особливостей під час пандемії коронавірусу не відображена у сучасних працях.

Мета статті - дослідити особливості дистанційного навчання у вишах України під час пандемії.

Виклад основного матеріалу. Вивчення вітчизняних і зарубіжних наукових праць педагогів, психологів, психолінгвістів, лінгвометодистів, психолого-педагогічної літератури свідчить про те, що дистанційне навчання - це форма організації та реалізації навчально-виховного процесу, за допомогою якої його учасники здійснюють навчальну взаємодію принципово і переважно екстериторіально (тобто на відстані, що не дозво- ляє і не передбачає безпосередню навчальну взаємодію учасників віч-на-віч, інакше, коли учасники територіально перебувають поза межами можливої безпосередньої навчальної взаємодії та коли у процесі навчання їх особиста присутність у певних навчальних аудиторіях вишів не $\epsilon$ обов'язковою) (Кухаренко, 2008: 9).

Так, дистанційне навчання розглядається як сучасний вид освітніх послуг, які надаються майже в усіх університетах світу впродовж п'ятдесяти років. Важливим завданням дистанційного навчання $\epsilon$ розвиток інтелектуальних $\mathrm{i}$ творчих здібностей особистості за допомогою вільного та відкритого використання усіх освітніх ресурсів і програм, у т. ч. доступних у мережі Інтернет (Застело, Підчасов, 2016).

Для реалізації дистанційного навчання за умов пандемії необхідно враховувати його особливості. Основними принципами системи дистанційної освіти, яка базується переважно на самостійному отриманні необхідного обсягу та якості знань і передбачає поєднання широкого спектру традиційних і новітніх інформаційних технологій, $€$ : гуманістичність, пріоритетність, відповідність технологіям навчання, гнучкість, модульність, неперервність, відкритість (Овчарук, 2016; Хуторський, 2013).

Розглянемо принципи системи дистанційної освіти детальніше.

Принцип гуманістичності навчання спрямований на створення сприятливих умов для опанування студентами соціального досвіду, закладеного у змісті навчання, освоєння обраної професії, для розвитку творчої особистості тощо.

Принцип пріоритетності педагогічного підходу полягає в тому, що проектування системи дистанційного навчання необхідно починати з розробки теоретичних концепцій, створення дидактичних моделей тих явищ, які передбачається реалізувати. Досвід комп'ютеризації дозволяє стверджувати, що, коли пріоритетним $є$ педагогічний аспект, система $є$ більш ефективною. Він потребує педагогічної оцінки ефективності кожного кроку проектування та створення системи дистанційного навчання. Тому на перший план необхідно ставити не впровадження техніки, а відповідне змістове наповнення навчальних курсів та освітніх послуг.

Принцип відповідності технологій навчання полягає у тому, що технології навчання мають бути адекватні моделям дистанційного навчання. Наприклад, у традиційних дисциплінарних моделях навчання як організаційні форми використовуються лекції, семінарські та практичні заняття, імітаційні або ділові ігри, лабораторні заняття, 
самостійна робота, виробнича практика, курсові та дипломні роботи, контроль засвоєння знань. У процесі становлення системи дистанційного навчання можуть з'являтися нові моделі, що в разі потреби мають бути включені до неї. Прикладом таких нових моделей можуть слугувати об'єктноорієнтовані або проектно-інформаційні моделі. Серед організаційних форм навчання в цих моделях будуть використовуватися комп'ютерні конференції, телеконференції, інформаційні сеанси, телеконсультації, проектні роботи тощо.

Принцип гнучкості, або мобільності навчання. Він передбачає можливість викладення матеріалу курсу з урахуванням підготовки, здібностей студентів, що досягається створенням альтернативних сайтів для одержання більш детальної або додаткової інформації з незрозумілих тем, підказок, створення інформаційних мереж, баз і банків знань і даних для дистанційного навчання, що дозволяють студенту коригувати або доповнювати свою освітню програму в необхідному напрямі за відсутності відповідних послуг у закладі освіти, де він навчається.

Модульний принцип навчання покладається за основу програми дистанційної освіти, що дозволяє 3 набору незалежних курсів-модулів сформувати навчальну програму, яка відповідає потребам студентів. Розбиття матеріалу на окремі функціонально завершені теми сприяють вивченню й засвоєнню матеріалу і відповідають здібностям студента або групи.

Принцип неперервності навчання, або безперервності освіти, спрямований на підготовку студентів до вдосконалення їхніх професійних якостей протягом усього життя: термін «навчання протягом усього життя» («life-long learning»).

Принцип відкритості навчання передбачає об'єктивність оцінки знань студентів, iї незалежність від викладача, оскільки використовуються сучасні комп'ютерні технології та відповідні програми виставлення оцінок за шкалою ЄКТС.

Визначення принципів дистанційної освіти дозволяє нам перейти до розгляду переваг такого формату навчання, до яких віднесемо:

- можливість самостійно планувати свою діяльність; приймати рішення, робити вибір і нести за нього відповідальність; відбирати необхідну інформацію, структурувати та використовувати ії для прийняття рішення;

- подання результатів діяльності з використанням інформаційних технологій;

- формування мобільності особистості, умінь швидко адаптуватися до умов, що змінюються непередбачувано і стрімко;
- формування глобального (національного, регіонального, міського, локального), принципово нового освітнього простору (Биков, 2005: 101);

- можливість займатися у зручний для себе час у зручному місці й темпі, нерегламентований відрізок часу для освоєння дисципліни;

- можливість користуватися джерелами навчальної інформації (електронними бібліотеками, банками даних, базами знань тощо);

- сконцентроване подання навчальної інформації та мультидоступ до неї, що підвищує ефективність засвоєння матеріалу;

- можливість витратити більше зусиль і часу на складні та важливі теми з метою поглибленого опрацювання;

- використання в освітньому процесі новітніх досягнень інформаційних і телекомунікаційних технологій, що також дає змогу навчати роботи 3 ними;

- рівні можливості одержання освіти незалежно від місця проживання, стану здоров'я, елітарності та матеріальної забезпеченості студента;

- дистанційне навчання допомагає оминути психологічні бар'єри, пов'язані з комунікативними якостями людини, наприклад, соромливістю, страхом публічних виступів тощо;

- дистанційне навчання розширює й оновлює роль викладача, котрий повинен координувати пізнавальний процес, постійно вдосконалювати свої курси, підвищувати творчу активність і кваліфікацію відповідно до нововведень та інновацій (Gudmundsdottir, 2018: 215);

- дистанційна освіта позитивно впливає на студента,збільшуючийоготворчийтаінтелектуальний потенціал за рахунок самоорганізації, прагнення до знань, уміння володіти комп'ютерною технікою і самостійно приймати відповідальні рішення;

- посилення мотивації до самоосвіти та саморозвитку;

- навчання за найбільш зручних умов - у комфортному темпі, але з оптимальним використанням часу, виокремленого для виконання певних завдань.

Незважаючи на переваги дистанційного навчання, викладачі та студенти зіштовхуються із деякими труднощами.

Викладачі не підготовані належним чином до організації створення необхідної навчальної інформації, перетворення ії в електронний освітній ресурс і розробки засобів передачі ії з максимальною ефективністю студентам. Як наслідок, викладач витрачає багато часу на розміщення необхідного матеріалу в мережі. В освітян виникають труднощі щодо організації курсу, а саме у розподіленні навчального матеріалу - що потрібно про- 
Зайцева I., Заслужена А. Специфіка дистанційного навчання за умов пандемії ...

ходити в очному режимі, що можна опрацювати та засвоїти позааудиторно / самостійно, які види завдань підходять для індивідуальних занять, а які - для роботи у групах. Під час дистанційного навчання збільшується навантаження викладачів, оскільки підготовка до викладання онлайн займає набагато більше часу, ніж за очного навчання.

Безліч труднощів виникає й у студентів під час дистанційного навчання, яке поки що залишається незвичним і складним із погляду психологічних установок (Zaytseva, 2020: 289-297). Викликом дистанційної форми навчання для здобувачів освіти, особливо студентів початкового етапу навчання, є відсутність або недостатня сформованість навичок самостійної роботи, оскільки більша частина навчального процесу складається саме із самостійної роботи студентів із засвоєння навчального матеріалу. До того ж, орієнтованість на технічні засоби, на віртуальне середовище, постійна концентрація на екрані монітора, тривале включення у віртуальний світ не може не відобразитися на внутрішньому стані студента.

Врахування сучасних вимог, визначення й аналіз труднощів дистанційного навчання, світовий i власний педагогічний досвід дозволяють нам здійснити аналіз пріоритетних стратегій із забезпечення та реалізації якісного освітнього процесу у кризовій ситуації. За умов, що склалися, першорядними завданнями для університетів стануть:

Стратегічне планування й облік супутніх ризиків для передбачення короткострокових і довгострокових наслідків пандеміі, включаючи очікуваний економічний спад.

Розробка заходів підтримки студентів і викладачів, що буде спрямована на вирішення таких завдань, як:

- пошук шляхів нівелювання нерівності між студентами (доступ до Інтернету, наявність необхідного обладнання у всіх студентів);

- організація тренінгів для професорськовикладацького складу щодо організації дистанційного та змішаного навчання, використання потенціалу навчальних платформ;

- організація спеціальної платформи для обміну досвідом між викладачами у сфері дистанційного та змішаного навчання, спільного пошуку вирішення труднощів, що виникають у процесі навчання, психологічної підтримки студентів.
- приведення у відповідність процедур і критеріїв оцінювання знань із новим онлайн-розкладом і педагогічними підходами, що дозволить забезпечити в майбутньому якість навчання й обгрунтованість фінальних оцінок;

- налагодження партнерства із зарубіжними університетами, які готові ділитися своїми ресурсами, досвідом, особливо у сфері дистанційного та змішаного навчання і наукової онлайн-співпраці;

- розробка нових критеріїв оцінювання студентів;

- розробка та впровадження дистанційного курсу.

Висновки. Таким чином, специфіка дистанційного навчання за умов пандемії коронавірусу вимагає не лише професійного та творчого підходу, але і прийняття серйозних організаційних заходів і не лише на рівні вищих навчальних закладів. Різноманітні трансформації, спричинені глобалізацією, зумовили потребу перегляду та переоцінки організації дистанційного навчання, вибору методів, інструментів навчання.

Перспективним напрямом подальшого дослідження є детальний аналіз впливу пандемії коронавірусу на якість вищої освіти та пріоритетних стратегій із забезпечення та реалізації якісного освітнього процесу у кризовій ситуації й подолання негативних наслідків пандемії в освітній галузі. Детальний аналіз ситуації представлений у науковому доробку колективу таких авторів, як О. В. Ковтун, Л. Ю. Султанова, С. П. Гринюк, М. О. Желуденко, І. В. Зайцева, А. А. Заслужена, котрі в рамках конкурсу «Наука для безпеки людини та суспільства» працюють над проєктом «Потенціал вищої освіти за умов пандемії: глобальний, європейський, національний виміри» (реєстраційний номер Проєкту: 2020.01/0172). Фінансування проєкту здійснюється Національним фондом досліджень України за кошти державного бюджету. Конкурс, ініційований Міністерством освіти і науки України разом із Національним фондом досліджень у травні 2020 р., спрямований на підтримку найкращих наукових проектів із вирішення питань безпеки людини, зокрема безпеки за умов COVID-19.

Сподіваємося, що наше дослідження буде корисним для освітньої спільноти під час розробки планів реагування на пандемію й управління. 


\section{СПИСОК ВИКОРИСТАНИХ ДЖЕРЕЛ}

1. Інформаційне забезпечення навчально-виховного процесу: інноваційні засоби технології : монографія / Биков В. Ю., Гриценчук О. О., Жук Ю. О., Іванюк І. В., Малицька І. Д. Київ : Атіка, 2005. 140 с.

2. Застело А. О. Психологічні основи організації інформаційно-освітнього середовища дистанційної освіти. Вісник Харківського національного педагогічного університету імені Г. С. Сковороди. Сер. Психологія. 2012. Вип. 42 (2). С. 19-29.

3. Концептуальні засади державної політики щодо розвитку англійської мови у сфері вищої освіти: проект / М-во освіти України. URL: https://mon.gov.ua/ua/news/mon-stvorilo-koncepciyu-rozvitku-anglijskoyi-v-universitetah-udodatku-riven-v1-obovyazkova-umova-vstupu-v2-vipusku-vikladannya-profilnih-disciplin-inozemnoyu-ta-movni-skriningi (дата звернення 05.05.2020).

4. Концепція розвитку педагогічної освіти : проект. М-о освіти і науки України. URL: https://mon.gov.ua/ua/news/ mon-proponuye-do-gromadskogo-obgovorennyaproekt-koncepciyi-rozvitku-pedagog ichnoyi-osviti.

5. Биков В. Ю., Кухаренко В. М. Технологія створення дистанційного курсу : навчальний посібник. Київ, 2008. $324 \mathrm{c}$.

6. Овчарук О. В. Концептуальні підходи до застосування технологій відкритої освіти та дистанційного навчання у зарубіжних країнах та їх роль у процесах модернізації освіти. Інформаційні технології $і$ засоби навчання. 2006 . № 1. URL: http://www.nbuv.gov.ua/ejournals/ITZN/em1/content/06o ovemp.html.

7. Підчасов С. В. Психологічні особливості побудови освітнього процесу із застосуванням дистанційних освітніх технологій. 2016. URL: http:// www.2016.moodlemoot.in.ua/course/view.php?id=110\&lang=ru.

8. Хуторской А.В.Принципыдистанционноготворческого обучения. 1998.URL:http://eidos.ru/journal/1998/1111-05. htm.

9. Gudmundsdottir G. B., Hatlevik, O. E. Newly qualified teachers' professional digital competence: Implications for teacher education. European Journal of Teacher Education. 2018. № 41 (2). P. 214-231.

10. Distance learning solutions. 2020 / UNESCO. URL: https://en.unesco.org/themes/education-emergencies.

11. Dluhopolskyi, O. On-line courses of foreign universities in a context of stimulating motivation for quality higher education. Innovative University and Leadership: project and microprojects. 2017. P. 142-151.

12. Klapkiv Y., Dluhopolska T. Changes in the Tertiary Education System in Pandemic Times: Comparison of Ukrainian and Polish Universities. Revista Românească pentru Educaţie Multidimensională. 2020. Vol. 12. Issue 1. Sup. 2. P. 86-91.

13. Dehmel A. Making a European area of lifelong learning a reality. Some critical reflections on the European Union's lifelong learning policies. Comparative Education. 2006. Vol. 42. №. 1. P. 49-62.

14. Prokopenko I., Berezhna, S. Higher Education Institutions in Ukraine during the Coronavirus, or COVID-19, Outbreak : New Challenges vs New Opportunities. Revista Romaneasca Pentru Educatie Multidimensionala. 2020. № 12 (1). P. 130-135.

15. Tam, G., El-Azar D. 3 ways the coronavirus pandemic could reshape education. 2020. URL: https://www.weforum. org/agenda.

16. Zaytseva I., Pysanko M., Lysenko O. Psycholinguistic Background of Training English Discussion Skills in Students of Philology Departments. International Journal of Higher Education. 2020. Vol. 9. № 7. P. 289-297.

\section{REFERENCES}

1. Bykov V. Yu., Hrytsenchuk O. O., Zhuk Yu. O., Ivaniuk I. V., Malytska I. D. Informatsiine zabezpechennia navchalno-vykhovnoho protsesu: innovatsiini zasoby tekhnolohiim [Information support of the educational process: innovative means of technologmy]. Akademiia pedahohichnykh nauk Ukrainy, Instytut zasobiv, 2005. 140 p. [in Ukrainian].

2. Zastelo A. O. Psykholohichni osnovy orhanizatsii informatsiino - osvitnoho seredovyshcha dystantsiinoi osvity. [Psychological foundations of informational-educational space organization of distance education]. Visnyk Kharkivskoho natsionalnoho pedahohichnoho universytetu imeni H. S. Skovorody. Ser. Psykholohiia., 2012, 42 (2), pp. 19-29 [in Ukrainian].

3. Kontseptualni zasady derzhavnoi polityky shchodo rozvytku anhliiskoi movy u sferi vyshchoi osvity: proekt [Conceptual principles of state policy for the development of English in higher education]. URL: https://mon.gov.ua/ua/news/ mon-stvorilo-koncepciyu-rozvitku-anglijskoyi-v-universitetah-u-dodatku-riven-v1-obovyazkova-umova-vstupu-v2-vipusku-vikladannya-profilnih-disciplin-inozemnoyu-ta-movni-skriningi [in Ukrainian].

4. Kontseptsiia rozvytku pedahohichnoi osvity [The concept of development of pedagogical education]. URL: https://mon.gov.ua/ua/news/mon-proponuye-do-gromadskogo-obgovorennyaproekt-koncepciyi-rozvitku-pedagogichnoyiosviti [in Ukrainian].

5. Bykov V. Yu., Kukharenko V. M. Tekhnolohiia stvorennia dystantsiinoho kursu [Technology of creating a distance course], navch. posibnyk, 2008. 324 p. [in Ukrainian].

6. Ovcharuk O. V. Kontseptualni pidkhody do zastosuvannia tekhnolohii vidkrytoi osvity ta dystantsiinoho navchannia $\mathrm{u}$ zarubizhnykh krainakh ta yikh rol u protsesakh modernizatsii osvity. [Conceptual approaches to the application of open education and distance learning technologies in foreign countries and their role in the processes of modernization of education]. Informatsiini tekhnolohii i zasoby navchannia, 2006. № 1. URL: http://www.nbuv.gov.ua/ejournals/ITZN/em1/ content/06oovemp.html. [in Ukrainian].

7. Pidchasov Ye. V. Psykholohichni osoblyvosti pobudovy osvitnoho protsesu iz zastosuvanniam dystantsiinykh osvitnikh tekhnolohii. [Psychological features of construction of educational process with application of distance educational technologies], 2016. URL: http://www.2016.moodlemoot.in.ua/course/view.php?id=110\&lang=ru [in Ukrainian]. 
8. Khutorskoi A. V. Pryntsypы dystantsyonnoho tvorcheskoho obuchenyia. [Principles of distance creative learning], 1998. URL: http://eidos.ru/journal/1998/1111-05.htm [in Russian].

9. Gudmundsdottir G. B., Hatlevik, O. E. Newly qualified teachers' professional digital competence: Implications for teacher education. European Journal of Teacher Education. 2018. № 41 (2). P. 214-231.

10. Distance learning solutions. 2020 / UNESCO. URL: https://en.unesco.org/themes/education-emergencies.

11. Dluhopolskyi, O. On-line courses of foreign universities in a context of stimulating motivation for quality higher education. Innovative University and Leadership: project and microprojects. 2017. P. 142-151.

12. Klapkiv Y., Dluhopolska T. Changes in the Tertiary Education System in Pandemic Times: Comparison of Ukrainian and Polish Universities. Revista Românească pentru Educaţie Multidimensională. 2020. Vol. 12. Issue 1. Sup. 2. P. 86-91.

13. Dehmel A. Making a European area of lifelong learning a reality. Some critical reflections on the European Union's lifelong learning policies. Comparative Education. 2006. Vol. 42. №. 1. P. 49-62.

14. Prokopenko I., Berezhna, S. Higher Education Institutions in Ukraine during the Coronavirus, or COVID-19, Outbreak: New Challenges vs New Opportunities. Revista Romaneasca Pentru Educatie Multidimensionala. 2020. № 12 (1). P. $130-135$.

15. Tam, G., El-Azar D. 3 ways the coronavirus pandemic could reshape education. 2020. URL: https://www.weforum. org/agenda.

16. Zaytseva I., Pysanko M., Lysenko O. Psycholinguistic Background of Training English Discussion Skills in Students of Philology Departments. International Journal of Higher Education. 2020. Vol. 9. № 7. P. 289-297. 